\title{
Prioritization of Selection Criteria for Halal Chicken Suppliers using Fuzzy AHP: A Case Study
}

\author{
Ibtihaaj Kamaruzaman ${ }^{*}$ and Pa'ezah Hamzah \\ Faculty of Computer and Mathematical Sciences, Universiti Teknologi MARA (UiTM), \\ 40450 Shah Alam, Selangor, Malaysia
}

\begin{abstract}
Muslim companies have yet to penetrate the business of supplying halal chicken to Malaysian supermarkets despite high demands for the product. To address this issue, this paper identifies the important criteria for selecting the product supplier at a supermarket chain and determines the order of importance of the criteria via Fuzzy Analytical Hierarchy Process (Fuzzy AHP). The criteria prioritization process involves pairwise ratings by a group of decision makers from the supermarket using five criteria and eight sub-criteria. Results show that, in order of importance, the supermarket emphasizes on ability to offer competitive pricing, product quality, strong financial position, order quantity flexibility, and product volume. The finding is useful for potential Muslim suppliers and relevant authorities in taking the necessary measures to increase participation of Muslim halal chicken suppliers in supermarkets
\end{abstract}

Keywords: Supplier selection criteria, Fuzzy AHP, Halal chicken, Supermarket

\section{INTRODUCTION}

Sourcing halal chicken meat from halal certified suppliers is an important concern among business enterprises to cater to the needs of Muslim consumers. The meat sold is considered halal if the breeding, slaughtering, packaging, transporting and storing of the poultry are conducted according to Syariah law. The poultry industry in Malaysia, however, are mainly (97\%) run by non-Muslim business owners (Wahab, 2014). Many supermarkets are also found to source out their supplies from non-Muslim owned enterprise (Kamaruzaman, 2018). There have been incidents where chicken supplied by non-Muslim suppliers to supermarkets did not conform to halal guideline, and thus considered non-halal (Md Zain, 2017; Shamsuri, 2019). For the benefits of Muslim community and intention of business penetration among Muslim suppliers, it is thus necessary to learn how suppliers of halal chicken are selected.

This paper addresses the selection of halal chicken suppliers at a supermarket chain with 145 branches nationwide. The daily supply of fresh halal chicken meat, in the magnitude of thousands of tonnes, is obtained from four companies owned by non-Muslims. The objectives of the study are to identify the key criteria used by the supermarket chain in selecting the current halal chicken suppliers and to determine the prioritization of the selection criteria based on Fuzzy Analytical Hierarchical (Fuzzy AHP) approach.

\section{MATERIALS AND METHODS}

Supplier selection is defined as the process of finding suppliers that are able to provide customers with products or services with the right quality, at the right price, quantity, and time (Jain et al., 2013). The selection process involves using multiple criteria of quantitative and qualitative natures. Three popularly used multiple criteria decisions making (MCDM) methods are the Analytic Hierarchy Process (AHP), Analytic Network Process (ANP), and Technique of Order Preference by Similarity to Ideal Solution (TOPSIS) (Mardani et. al., 2015). Search of the 
literature shows that not many studies were done on supplier selection in the food industry. Table 1 shows some of the criteria and MCDM methods applied in this industry. AHP was first introduced by Saaty in 1977.

Table 1. Supplier Selection Criteria and MCDM Methods in the Food Industry

\begin{tabular}{|c|c|c|c|c|c|c|c|c|}
\hline & \multirow[b]{2}{*}{ Criteria } & \multicolumn{6}{|c|}{ Authors } & \multirow[b]{2}{*}{ Tota } \\
\hline & & $\begin{array}{l}\text { Razak } \\
\text { et al. } \\
\text { (2016) }\end{array}$ & $\begin{array}{c}\text { Ramlan et al. } \\
\text { (2016) }\end{array}$ & $\begin{array}{c}\text { Othman et al. } \\
\text { (2016) }\end{array}$ & $\begin{array}{c}\text { Hansen } \\
\text { (2016) }\end{array}$ & $\begin{array}{l}\text { Yuan et a.l } \\
\text { (2015) }\end{array}$ & $\begin{array}{l}\text { Abbad \& } \\
\text { Pache } \\
\text { (2013) }\end{array}$ & \\
\hline 1 & Halal certification & $\mathbf{x}$ & & $\mathbf{x}$ & & & & 2 \\
\hline 3 & Raw materials & $\mathbf{x}$ & & $\mathbf{x}$ & & & & 2 \\
\hline 4 & Storage & $\mathbf{x}$ & & $\mathbf{x}$ & & & $\mathbf{x}$ & 3 \\
\hline 5 & $\begin{array}{l}\text { Knowledge on halal } \\
\text { concept }\end{array}$ & $\mathbf{x}$ & & $\mathbf{x}$ & & & & 2 \\
\hline 7 & Transportation & & & $\mathbf{x}$ & & & $\mathbf{x}$ & 2 \\
\hline 8 & Product Quality & & $\mathbf{x}$ & & $\mathbf{x}$ & $\mathbf{x}$ & $\mathbf{x}$ & 4 \\
\hline 9 & R\&D capability & & & & & $\mathbf{x}$ & & 1 \\
\hline 10 & Staff & $\mathbf{x}$ & & $\mathbf{x}$ & & & & 2 \\
\hline 11 & $\begin{array}{l}\text { Organizational } \\
\text { management }\end{array}$ & & $\mathbf{x}$ & $\mathbf{x}$ & & & & 2 \\
\hline 12 & Equipment and utensil & & & $\mathbf{x}$ & & & & 1 \\
\hline 17 & Business strategy & & & & & $\mathbf{x}$ & & 1 \\
\hline 18 & Supplier reliability & & & & $\mathbf{x}$ & & & 1 \\
\hline 19 & Production capacity & & & & $\mathbf{x}$ & & $\mathbf{x}$ & 2 \\
\hline 20 & Promotion & & & & & & $\mathbf{x}$ & 1 \\
\hline 21 & Delivery & & $\mathbf{x}$ & & & $\mathbf{x}$ & & 2 \\
\hline & MCDM Method & AHP & AHP & Regression & $\begin{array}{l}\text { t-test \& } \\
\text { ANOVA }\end{array}$ & $\begin{array}{c}\text { SWOT-Entropy } \\
\text { Weight Fuzzy } \\
\text { Comprehensive Model }\end{array}$ & $\begin{array}{l}\text { Qualitative } \\
\text { Approach }\end{array}$ & \\
\hline
\end{tabular}

It takes the pairwise comparisons of different alternatives with respect to various criteria and provides a decision support tool for MCDM problems (Saadon et al., 2010). However, the technique is said to be lacking in defining uncertain and unstable situations. Accordingly, fuzzy set theory has been integrated into AHP to allow for more accurate description of the decision-making process (Kien \& Thach, 2018). This study employs the Fuzzy Analytical Hierarchy Process (Fuzzy AHP) approach by Ali et. al., (2012).

\section{A. $\quad$ Fuzzy Set Theory and Fuzzy Numbers}

Fuzzy Set Theory was introduced by Zadeh in 1965 to measure the ambiguity arising from uncertainties and vagueness of human thought (Farokh, 2016). Fuzzy sets contain elements which have degrees of membership, $\mu(x)$,in the interval $[0,1]$. There are many shapes of fuzzy numbers. The triangular fuzzy number (TFN) has been widely used in research.

A TFN $\tilde{A}$ can be defined as $\tilde{A}=(l, m, u)$ where $l$ is the lower bound, $m$ the modal value and $u$ the upper bound. The membership function of a TFN is given by:

$$
\mu_{\tilde{A}}(x)=\left\{\begin{array}{c}
0, \text { for } x<1 \\
\frac{x-1}{m-1}, \text { for } 1 \leq x \leq m \\
\frac{u-x}{u-m}, \text { for } m \leq x \leq u \\
0, \quad \text { for } x>u
\end{array}\right\}(1)
$$

The TFNs for the linguistic variables as defined by Ali et al. (2012) are indicated in Table 2and illustrated in Figure 1

Table 2. Linguistic Scales and TFN

\begin{tabular}{lc}
\hline \multicolumn{1}{c}{ Linguistic Scales } & TFN $(\boldsymbol{l}, \boldsymbol{m}, \boldsymbol{u})$ \\
\hline Equally important (EI) & $(1,1,3)$ \\
Moderately important (MI) & $(1,3,5)$ \\
Strongly important (SI) & $(3,5,7)$ \\
Very strongly important (VS) & $(5,7,9)$ \\
Absolutely important (AI) & $(7,9,9)$ \\
\hline
\end{tabular}

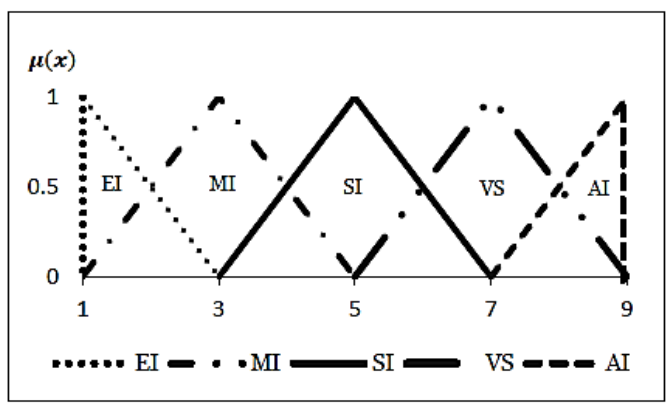

Figure 1. Linguistic Scale of the Weights of Criteria 


\section{B. Algebraic Operations with TFN}

The algebraic operations for any given real number $k \geq 0$ and two TFNs $\tilde{A}=\left(l_{1}, m_{1}, u_{1}\right)$ and $\tilde{B}=\left(l_{2}, m_{2}, u_{2}\right)$, where $l_{1}, l_{2} \geq 0$, are as follows:

$$
\begin{aligned}
& \text { Addition: } \tilde{A} \oplus \tilde{B}=\left(l_{1}+l_{2}, m_{1}+m_{2}, u_{1}+u_{2}\right) \\
& \text { Multiplication: } \tilde{A} \otimes \tilde{B}=\left(l_{1} \times l_{2}, m_{1} \times m_{2}, u_{1} \times u_{2}\right) \\
& \qquad k \times \tilde{A}=\left(k \times l_{1}, k \times m_{1}, k \times u_{1}\right) \\
& \text { Subtraction: } \tilde{A}(-) \tilde{B}=\left(l_{1}-l_{2}, m_{1}-m_{2}, u_{1}-u_{2}\right) \\
& \text { Division: } \tilde{A}(\div) \tilde{B}=\left(l_{1} \div l_{2}, m_{1} \div m_{2}, u_{1} \div u_{2}\right) \\
& \qquad \frac{\tilde{A}}{k}=\left(\frac{l_{1}}{k}, \frac{m_{1}}{k}, \frac{u_{1}}{k}\right)
\end{aligned}
$$

Inverse: $\tilde{A}^{-1}=\left(\frac{1}{u_{1}}, \frac{1}{m_{1}}, \frac{1}{l_{1}}\right)$

\section{Computational Procedure of Fuzzy}

\section{AHP}

Fuzzy AHP embeds the fuzzy theory to basic AHP model, which is widely used as decision making tool in solving MCDM problems. The Fuzzy AHP procedure by Ali et. al., (2012) is as follows:

Step 1: Compare the criteria, $C$, with the linguistic scales in Table 2. The pairwise comparison matrix $\tilde{A}^{k}$ is given in Equation 9, where $\tilde{a}_{i j}^{k}$ indicates the $k^{\text {th }}$ decision maker's preference of $i^{\text {th }}$ criterion over $j^{\text {th }}$ criterion, via TFNs where $i=1,2, \ldots, 5, j=1,2, \ldots, 5, k=1,2, \ldots, 5$ and $n$ is the number of criteria.

$$
\tilde{A}^{k}=\left[\begin{array}{cccc}
\tilde{a}_{11}^{k} & \tilde{a}_{12}^{k} & \ldots & \tilde{a}_{1 n}^{k} \\
\tilde{a}_{21}^{k} & \ldots & \ldots & \tilde{a}_{2 n}^{k} \\
\ldots & \ldots & \ldots & \ldots \\
\tilde{a}_{n 1}^{k} & \tilde{a}_{n 2}^{k} & \ldots & \tilde{a}_{n n}^{k}
\end{array}\right]
$$

Step 2: Construct the synthetic pairwise comparison matrix, $\tilde{A}$, with respect to the main goal as Equation 10.

$$
\tilde{A}=\left[\begin{array}{ccc}
\tilde{a}_{11} & \cdots & \tilde{a}_{1 n} \\
\vdots & \ddots & \vdots \\
\tilde{a}_{n 1} & \cdots & \tilde{a}_{n n}
\end{array}\right](10)
$$

The element, $\tilde{a}_{i j}$, is determined using Equation 11.

$$
\tilde{a}_{i j}=\left(\prod_{i=1, j=1}^{n} a_{i j}\right)^{\frac{1}{k}}=\left(\tilde{a}_{i j}^{1} \otimes \tilde{a}_{i j}^{2} \otimes \cdots \otimes \tilde{a}_{i j}^{k}\right)^{\frac{1}{k}}
$$

Step 3: Calculate the fuzzy geometric means, $\tilde{r}_{i}$ where

$$
\tilde{r}_{i}=\left(\prod_{j=1}^{n} a_{i j}\right)^{\frac{1}{n}}=\left(\tilde{a}_{i 1} \otimes \tilde{a}_{i 2} \otimes \cdots \otimes \tilde{a}_{i n}\right)^{\frac{1}{n}}
$$

Step 4: Find the fuzzy weight for each criterion, $\widetilde{W}_{i}$ using Equation 13.

$$
\widetilde{\mathrm{W}}_{\mathrm{i}}=\tilde{\mathrm{r}}_{\mathrm{i}} \otimes\left(\tilde{\mathrm{r}}_{1} \oplus \widetilde{\mathrm{r}}_{2} \oplus \cdots \oplus \tilde{\mathrm{r}}_{\mathrm{n}}\right)^{-1}
$$

Step 5: Perform defuzzification to convert the fuzzy numbers to crisp values to obtain the Best Non-Fuzzy Performance (BNP) using the Center of Area method as follows:

$$
B N P_{W_{i}}=\frac{\left(\left(U_{W_{i}}-L_{W_{i}}\right)+\left(M_{W_{i}}-L_{W_{i}}\right)\right)}{3}+L_{W_{i}}
$$

This step is necessary since fuzzy numbers, which are in interval form cannot be used to determine rankings. Based on BNP, the higher the value, the higher the rank. Defuzzification to BNP has also been employed in the studies by Yilmaz (2017), and Huynh et al. (2018).

\section{Fuzzy AHP Implementation}

\section{Phase One: Criteria and Sub-criteria Selection}

The criteria and sub-criteria for evaluating potential halal chicken suppliers were selected based on operation performance measures currently practiced by the supermarket and suggestion from the literature. From an interview with the decision makers, it was revealed that the supermarket considers six key criteria: halal certification, capacity, delivery time, packaging, production process, and certification associated with poultry and food regulations. Suppliers must be able to deliver the chicken, in the magnitude of tens of thousands of tonnes, on daily basis and on time in ready packaging.

Halal certification, can be obtained from the Department of Islamic Development Malaysia (JAKIM), is necessary to ensure that the whole supply chain is halal (Razak et. al., 2016). Additionally, the supermarket requires that each supplier is capable of monitoring the entire production process to ensure it is in accordance with the Syariah Law. Since in the selection process, all suppliers are assumed to already have complied to the stringent halal criterion, this criterion is excluded from this prioritization study. Altogether, there are five criteria and eight subcriteria, as described in Table 3 and structured into a hierarchical model in Figure 2. 
Table 3. Description of Criteria and Sub-criteria

\begin{tabular}{|c|c|c|}
\hline Criteria & $\begin{array}{c}\text { Sub- } \\
\text { Criteria }\end{array}$ & Description \\
\hline \multirow[t]{2}{*}{ Quality $\left(\boldsymbol{C}_{\boldsymbol{I}}\right)$} & $\begin{array}{l}\text { Product } \\
\text { quality }\left(\boldsymbol{C}_{\mathbf{n}}\right)\end{array}$ & $\begin{array}{l}\text { Good quality chicken and } \\
\text { meet company } \\
\text { standards. }\end{array}$ \\
\hline & $\begin{array}{l}\text { Source of } \\
\text { chicken }\left(C_{\boldsymbol{z}}\right)\end{array}$ & $\begin{array}{l}\text { Poultry is sourced out } \\
\text { from supplier's own farm } \\
\text { and supplier have direct } \\
\text { control on poultry's } \\
\text { feeding and breeding. }\end{array}$ \\
\hline \multirow[t]{2}{*}{$\begin{array}{l}\text { Dependa- } \\
\text { bility } \\
\left(\boldsymbol{C}_{\boldsymbol{z}}\right)\end{array}$} & Capacity $\left(\boldsymbol{C}_{\boldsymbol{z} \boldsymbol{x}}\right)$ & $\begin{array}{l}\text { Supplier is capable to } \\
\text { fulfil supermarket } \\
\text { orders. }\end{array}$ \\
\hline & $\begin{array}{l}\text { Delivery time } \\
\left(C_{z z}\right)\end{array}$ & $\begin{array}{l}\text { Supplier consistently } \\
\text { meets a promised } \\
\text { delivery time. }\end{array}$ \\
\hline \multirow[t]{2}{*}{$\begin{array}{l}\text { Flexibility } \\
\left(\boldsymbol{C}_{3}\right)\end{array}$} & $\begin{array}{l}\text { Volume } \\
\text { flexibility } \\
\left(C_{32}\right)\end{array}$ & $\begin{array}{l}\text { Supplier is able to supply } \\
\text { below/above normal } \\
\text { order quantity. }\end{array}$ \\
\hline & $\begin{array}{l}\text { Delivery } \\
\text { flexibility } \\
\left(\boldsymbol{C}_{3 z}\right)\end{array}$ & $\begin{array}{l}\text { Supplier is able to react } \\
\text { to changes in the timing } \\
\text { of delivery. }\end{array}$ \\
\hline \multirow[t]{2}{*}{ Cost $\left(\boldsymbol{C}_{4}\right)$} & Price $\left(C_{41}\right)$ & $\begin{array}{l}\text { Supplier can supply } \\
\text { chickens at competitive } \\
\text { price. }\end{array}$ \\
\hline & $\begin{array}{l}\text { Transpor- } \\
\text { tation cost } \\
\left(\boldsymbol{C}_{4=}\right)\end{array}$ & $\begin{array}{l}\text { Cost to deliver chicken to } \\
\text { supermarkets. }\end{array}$ \\
\hline $\begin{array}{l}\text { Financial } \\
\text { Position }(C\end{array}$ & \multicolumn{2}{|c|}{ Supplier has strong financial position. } \\
\hline
\end{tabular}

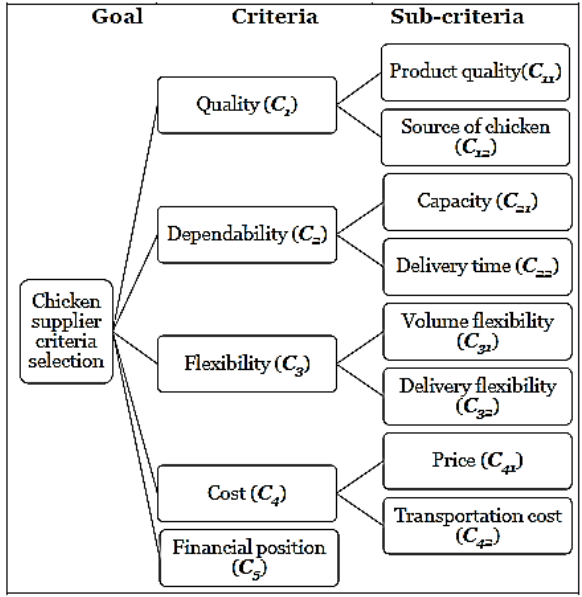

Figure 2. Hierarchical Model

2. Phase Two: Questionnaire Development and Data

\section{Collection}

A set of questionnaires was developed and reviewed by a group of five (5) decision makers. They had been involved in the selection of the current chicken suppliers. The decision makers' responds were used to construct five (5) pairwise comparison matrices where the criteria were arranged in a square matrix of $5 \times 5$ as shown in Figure 3.

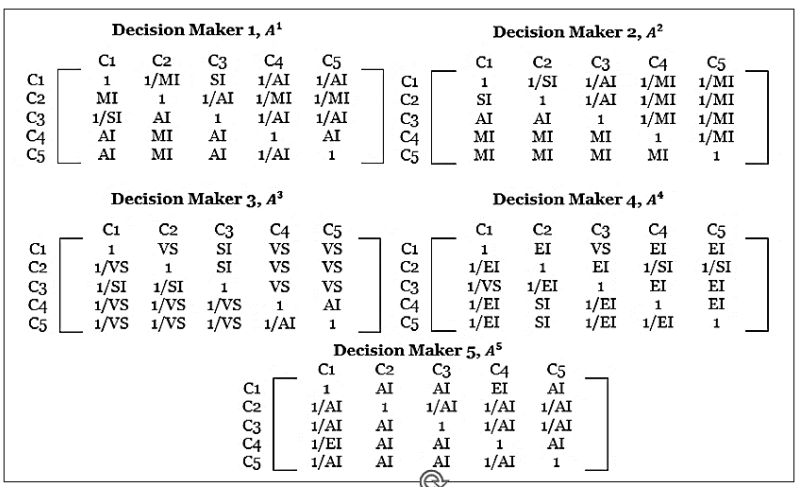

Figure 3. Five pairwise comparison matrices for all criteria

\section{Phase Three: Fuzzy AHP Application}

Fuzzy AHP computations were performed on Microsoft Excel to find the weights and ranking of the criteria and sub-criteria. The ratings by the decision makers based on the linguistic scales in Table 2 were transformed into TFNs to construct the comparison matrices, $\tilde{A}^{k}$,using Equation 9. However, the matrices are not included in this paper due to space constraint.

Next, synthetic pairwise comparison matrix for the group of decision makers, $\tilde{A}$, was constructed using Equation 10 as shown in Figure 4. The synthesis values $\tilde{a}_{i j}$ with respect to each criterion were calculated using Equation 11. As an example, the calculation for element $\tilde{a}_{12}$ of matrix $\tilde{A}$ is as follows:

$$
\begin{gathered}
\tilde{a}_{12}=\left(\tilde{a}_{12}^{1} \otimes \tilde{a}_{12}^{2} \otimes \tilde{a}_{12}^{3} \otimes \tilde{a}_{12}^{4} \otimes \tilde{a}_{12}^{5}\right)^{\frac{1}{5}} \\
=\left(\frac{1}{M I} \otimes \frac{1}{S I} \otimes V S \otimes E I \otimes A I\right)^{\frac{1}{5}} \\
=\left(\left(\frac{1}{5}, \frac{1}{3}, 1\right) \otimes\left(\frac{1}{7}, \frac{1}{5}, \frac{1}{3}\right) \otimes(5,7,9) \otimes(1,1,3)\right. \\
\otimes(7,9,9))^{\frac{1}{5}}
\end{gathered}
$$

$=(1.000,1.332,2.408)$

Next, the fuzzy geometric means, $\tilde{r}_{i}$ is obtained using Equation 12. For example,

$$
\begin{aligned}
& \tilde{r}_{1}=\left(\tilde{a}_{11} \otimes \tilde{a}_{12} \otimes \tilde{a}_{13} \otimes \tilde{a}_{14} \otimes \tilde{a}_{15}\right)^{\frac{1}{5}} \\
& =\left((1 \times 1 \times \ldots \times 0.951)^{\frac{1}{5}},(1 \times 1.332 \times \ldots \times 1.185)^{\frac{1}{5}},\right.
\end{aligned}
$$

$\left.(1 \times 2.408 \times \ldots \times 2.033)^{\frac{1}{5}}\right)$

$$
=(1.045,1.2761 .953)
$$

$$
\tilde{r}_{2}=\left(\begin{array}{lll}
0.425, & 0.559, & 0.836
\end{array}\right)
$$




$$
\begin{aligned}
& \tilde{r}_{3}=\left(\begin{array}{lll}
0.611, & 0.747, & 1.030
\end{array}\right) \\
& \tilde{r}_{4}=\left(\begin{array}{lll}
1.138, & 1.782, & 2.229
\end{array}\right) \\
& \tilde{r}_{5}=\left(\begin{array}{lll}
0.676, & 1.052, & 1.280
\end{array}\right)
\end{aligned}
$$

The fuzzy weight for each criterion, $\widetilde{W}_{i}$, can be obtained using Equation 13. As an example,

$\widetilde{W}_{1}=\tilde{r}_{1} \otimes\left(\tilde{r}_{1} \oplus \tilde{r}_{2} \oplus \tilde{r}_{3} \oplus \tilde{r}_{4} \oplus \tilde{r}_{5}\right)^{-1}$

$=(1.045,1.2761 .953) \otimes$

$((1.045+0.425+\ldots+0.676)$,

$$
\begin{aligned}
& (1.276+0.559+\ldots+1.052),(1.953+0.836 \\
& +\ldots+1.280))^{-1}
\end{aligned}
$$

$=(1.045,1.2761 .953) \otimes(0.136,0.185,0.257)$

$=(0.143,0.236,0.501)$

$\widetilde{W}_{2}=\left(\begin{array}{lll}0.058, & 0.103, & 0.215\end{array}\right)$
$\widetilde{W}_{3}=\left(\begin{array}{lll}0.083, & 0.138, & 0.265\end{array}\right)$
$\widetilde{W}_{4}=\left(\begin{array}{lll}0.155, & 0.329, & 0.572\end{array}\right)$
$\widetilde{W}_{5}=\left(\begin{array}{lll}0.092, & 0.194, & 0.329\end{array}\right)$

Lastly, these fuzzy weights are defuzzified using Equation 14 to determine their BNP values. For example,

$$
\begin{aligned}
B N P_{W_{1}} & =\frac{\left(\left(U_{W_{1}}-L_{W_{1}}\right)+\left(M_{W_{1}}-L_{W_{1}}\right)\right)}{3}+L_{W_{1}} \\
& =\frac{((0.501-0.143)+(0.236-0.143))}{3}+0.143 \\
& =0.293
\end{aligned}
$$

The BNP values for the criteria are shown in Table 4 .
Similar steps are applied to compute the BNP values for all eight sub-criteria.

\section{RESULTS AND DISCUSSIONS}

Table 4 shows the results of Fuzzy AHP computations for ranking the five criteria and eight sub-criteria in selecting halal chicken suppliers at the supermarket under study.

Fuzzy AHP ranks cost as the most important criterion for the company in selecting their halal chicken suppliers as it has the highest BNP value of 0.352. This is followed by

\begin{tabular}{|c|c|c|c|c|}
\hline Criteria & BNP & Rank & Sub-criteria & BNP \\
\hline \multirow{2}{*}{ Quality } & \multirow{2}{*}{0.293} & \multirow{2}{*}{2} & Product quality & 0.519 \\
\hline & & & Source of chicken & 0.501 \\
\hline \multirow{2}{*}{$\begin{array}{l}\text { Depend- } \\
\text { ability }\end{array}$} & \multirow{2}{*}{0.125} & \multirow{2}{*}{5} & Capacity & 0.820 \\
\hline & & & Delivery time & 0.223 \\
\hline \multirow[b]{2}{*}{ Flexibility } & \multirow[b]{2}{*}{0.162} & \multirow[b]{2}{*}{4} & Volume flexibility & 0.538 \\
\hline & & & $\begin{array}{l}\text { Delivery } \\
\text { flexibility }\end{array}$ & 0.499 \\
\hline \multirow[b]{2}{*}{ Cost } & \multirow[b]{2}{*}{0.352} & \multirow[b]{2}{*}{1} & Price & 0.891 \\
\hline & & & $\begin{array}{l}\text { Transportation } \\
\text { cost }\end{array}$ & 0.125 \\
\hline $\begin{array}{l}\text { Financial } \\
\text { position }\end{array}$ & 0.205 & 3 & & \\
\hline
\end{tabular}
quality (0.293), financial position (0.205), flexibility (0.162)

\begin{tabular}{|c|c|c|c|c|c|c|c|c|c|c|c|c|c|c|c|}
\hline & & $C_{t}$ & & & $\mathrm{C}_{2}$ & & & $C_{3}$ & & & $c_{4}$ & & & $C_{5}$ & \\
\hline $\mathrm{Cl}_{1}$ & $(1.000$ & 1.000 & $1.000)$ & (1.00o, & 1.332, & $2.408)$ & $(2.036$ & 2.809 & $3.554)$ & $(0.644)$ & 0.763, & $1.632)$ & $(0.951$, & 1.185 & 2.033) \\
\hline $\mathrm{C}_{2}$ & $(0.45$, & 0.750 & $1.000)$ & $(1.000$ & 1.000 & $1.000)$ & (0.333, & 0.369 & $0.572)$ & (0.316, & 0.444 & $0.844)$ & (0.316, & 0.444 & $0.844)$ \\
\hline$C_{3}$ & (0.281, & 0.356 & $0.491)$ & $(1.748$ & 2.709 & $3.000)$ & (1.000, & 1.000 & $1.000)$ & $(0.415)$ & 0.492 , & $0.888)$ & $(0.455$ & 0.492 & $0.888)$ \\
\hline$C_{4}$ & $(0.613)$ & 1.310 & $\left.1.55^{2}\right)$ & $\left(1.18_{5}\right.$ & 2.251 & $3.160)$ & $(1.127$ & 2.033, & $2.408)$ & (1.000, & 1.000 & $1.000)$ & (2.330, & 3.000 & $4656)$ \\
\hline$C_{5}$ & $(0.492$, & 0.844 & $1.052)$ & $(1.185$, & 2.251 & $3.160)$ & $(1.127$ & 2.033 & $2.408)$ & (0.225, & 0.333 & $0.429)$ & $(1.000$ & 1.000 & $1.000)$ \\
\hline
\end{tabular}
and dependability (0.125).

Under cost criterion, the sub-criterion price (0.891) is more important than transportation cost (0.125). Under quality criterion, product quality (0.519) is more important if compared to source of chicken (0.501).

Table 4. Priorities for All Criteria and Sub-criteria

Figure 4. Synthetic pairwise comparison matrices for criteria, $\tilde{A}$

For flexibility criterion, volume flexibility (0.538) is more important than delivery flexibility (0.499). Lastly, for dependability criterion, the sub-criterion of capacity (o.820) is weighted higher than delivery time (0.223).

Since cost is the most important criterion, this means that halal chicken suppliers must be able to offer 
competitive price to the supermarket and charge reasonable transportation cost for delivery of chickens to all supermarket branches in order to be selected as their supplier. The second most important criterion is quality, where halal chicken to be supplied to the supermarket must meet their standards and must be sourced out from the supplier's own farm. The third most important criterion is financial position. The supermarket expects the suppliers to have strong financial position to ensure long term supply. Thus, Muslim companies should focus and improve on the three aspects in order to penetrate the supermarkets.

Nevertheless, suppliers must also comply to the criteria of flexibility and dependability. These mean that suppliers must be able to react to changes in the timing and order quantity as well as timely delivery in supplying thousands of tonnes of halal chicken on daily basis.

\section{CONCLUSION \& RECOMMENDATIONS}

The contributions of this study are the identification of important criteria for selecting halal chicken suppliers for the supermarket chain under study and the prioritization of five criteria in the order of their importance using Fuzzy AHP. Based on the preference of the experts from the supermarket, it is found that cost, quality and financial position are the top three most important criteria for selecting halal chicken suppliers.

The ranking of criteria for selecting halal chicken suppliers established in this study can be used as a reference for Muslim chicken suppliers to improve their business strategy in order to penetrate the supermarket business. Extra attention should be given to the top three selection criteria, which are cost, quality and financial position without neglecting two other important criteria, which are flexibility and dependability.

Relevant government agency can use the findings of this study to design strategies to increase the participation of Muslim suppliers in the market. At the same time, the supermarket should consider relaxing certain criteria such as financial position to give Muslim chicken suppliers the opportunity to do business.

Overall, this study shows that Fuzzy AHP is successful in ranking selection criteria for the supermarket halal chicken suppliers. Future study should include more supermarket operators and explore other fuzzy MCDM methods.

\section{ACKNOWLEDGEMENTS}

The authors wish to thank the management of the supermarket under study for their cooperation and, the Faculty of Computer and Mathematical Sciences, Universiti Teknologi MARA, Shah Alam for the financial support given. 


\section{REFERENCES}

Abbad, H., \& Paché, G. 2013, The impact of logistical criteria in the selection of SMEs by large food retailersa case study in an emerging country. Problems and Perspectives in Management, 11(1).

Ali, N. H., Sabri, I. A., Noor, N. M., \& Ismail, F. 2012, Rating and ranking criteria for selected islands using Fuzzy Analytic Hierarchy Process (FAHP). International Journal of Applied Mathematics and Informatics, 1(6), 57-65.

Farrokh, M., Heydari, H., \& Janani, H. 2016, Two comparative MCDM approaches for evaluating the financial performance of Iranian basic metals companies. Iranian Journal of Management Studies, $9(2), 359-382$.

Hansen, K. 2016, Purchasing decision behaviour by Chinese supermarkets. The International Review of Retail, Distribution and Consumer Research, 11(2).

Huynh, V. D. B., Nguyen, V. P., Nguyen, Q. L. H. T. T., \& Nguyen, P. T. 2018, Application of Fuzzy Analytical Hierarchy Process based on Geometric Mean Method to prioritize social capital network indicators. International Journal of Advanced Computer Science and Applications (IJACSA), 9(12), 182-186.

Jain, R., Singh, A. R., \& Mishra, P. K. (2013). Prioritization of supplier selection criteria: A Fuzzy-AHP approach. MIT International Journal of Mechanical Engineering, 3(1).

Kamaruzaman, I. 2018, Application of Fuzzy AHP for ranking selection criteria for supermarket halal chicken suppliers. (Unpublished master's dissertation). Universiti Teknologi MARA, Shah Alam, Selangor, Malaysia.

Kien, P. V., \& Thach, N. N. 2018, A study on optimal outsourcing service nation in the East and Southeast Asian Region: A comparison between AHP and Fuzzy AHP approach. International Econometric Conference of Vietnam, 831-858.

Mardani, A., Jusoh, A., \& Zavadskas, E. K. 2015, Fuzzy Multiple Criteria Decision-Making techniques and applications: Two decades review from 1994 to 2014. Expert Systems with Applications, 42(8).

Md Zain, R. 2017, October 17, JAIS sita 1098 ayam, Berita Harian Online. Retrieved from

https://www.bharian.com.my/berita/wilayah/2017/10/33 8685/jais-sita-1098-ayam

Othman, B., Md Shaarani, S., \& Bahron, A. 2016, An empirical analysis of Halal practices on organizational performance among food industries. International Journal of Current Research, 8(3).

Ramlan, R., Bakar, E. M. N. E. A., Mahmud, F., \& Ng, H. K. 2016, The ideal criteria of supplier selection for SMEs food processing industry. In MATEC Web of Conferences.

Razak, A. R., Iberahim, H., \& Kamaruddin, R. 2016, Criteria Selection for halal casual dining restaurant. In Proceedings of the 1st AAGBS International Conference on Business Management 2014 (AiCoBM2014), 257267.

Saadon, N. A. M., Dom, R. M., \& Mohamad, D. 2010, Comparative analysis of criteria weight determination in AHP models. In 2010 International Conference on Science and Social Research (CSSR2010), 965-969.

Shamsuri, A. S. 2019, April 03, Pusat penyembelihan ayam tiada sijil halal diserbu, Kosmo Online. Retrieved from

https://www.kosmo.com/negara/pusat-sembelihan-ayamtiada-sijil-halal-diserbu-1.875621

Wahab, A. G. 2014, Malaysia Broiler Meat Sector. USDA Foreign Agriculture Service. Global Agricultural Information report.

Yilmaz, Z. 2017, A Fuzzy AHP-TOPSIS model-based case study for selecting vehicles to buy CASCO insurance under limited budget. Pamukkale University Journal of Social Sciences Institute.

Yuan, Y., Zhang, Y., Di, L., Wu, G. G., \& Yang, Z. X. 2015, Research on large supermarket fresh food supplier evaluation and selection based on SWOT-Entropy Weight Fuzzy Comprehensive model. In Proceedings of the 2015 International Conference on Advanced Mechatronic Systems (ICAMechS), 15-19. 